\title{
Pedo-Transfer Functions to Estimate Kinetic Parameters for Anaerobic Soil Nitrogen Mineralization
}

\author{
Ganghua Zou ${ }^{1}$, Fengliang Zhao ${ }^{1 *}$, Ying Shan ${ }^{1}$, Yong Li $^{2 *}$ \\ ${ }^{1}$ Environment and Plant Protection Institute, Chinese Academy of Tropical Agricultural Sciences, Hainan, China \\ ${ }^{2}$ Changsha Research Station for Agricultural \& Environmental Monitoring and Key Laboratory of Agro-Ecological Processes in \\ Subtropical Region, Institute of Subtropical Agriculture, Chinese Academy of Sciences, Hunan, China \\ Email: *zfl7409@163.com, ${ }^{\star}$ yli@isa.ac.cn
}

How to cite this paper: Zou, G.H., Zhao, F.L., Shan, Y. and Li, Y. (2018) Pedo-Transfer Functions to Estimate Kinetic Parameters for Anaerobic Soil Nitrogen Mineralization. Open Journal of Soil Science, 8, 75-86. https://doi.org/10.4236/ojss.2018.82006

Received: January 2, 2017

Accepted: February 10, 2018

Published: February 13, 2018

Copyright $\odot 2018$ by authors and Scientific Research Publishing Inc. This work is licensed under the Creative Commons Attribution International License (CC BY 4.0).

http://creativecommons.org/licenses/by/4.0/

\section{c) (i) Open Access}

\begin{abstract}
Knowledge of potential anaerobic soil $\mathrm{N}$ mineralization is important for nitrogen fertilizer application. Instead of time-consuming laboratory incubation, we attempt to use pedo-transfer functions (PTFs) approach to get this information. 27 soil samples with various soil depths were collected from paddy field, woodland and tea field in subtropical central China, anaerobically incubated at $35^{\circ} \mathrm{C}$ for 7 weeks to determine $\mathrm{N}$ mineralization, which was fitted by a modified double exponential model with two parameters (the fraction of active $\mathrm{N}$ pool $(f)$ and mineralization rate constant $(k)$ for active $\mathrm{N}$ pool). The PTFs for parameters were developed from significant soil properties using multiple stepwise regression method. Parameter $f$ (range: 1.59\% - 10.4\%, mean: $5.2 \%)$ was mainly correlated with soil total $\mathrm{N}(T \mathrm{~N})$, organic $\mathrm{C}(\mathrm{SOC})$, sand and silt particle contents $(\mathrm{r}=-0.59-0.69, p<0.01)$, and parameter $k$ (range: $0.027-0.155 \mathrm{~d}^{-1}$, mean: $0.97 \mathrm{~d}^{-1}$ ) was significantly related to $T \mathrm{~N}$, SOC, clay content, $\mathrm{C}$ to $\mathrm{N}$ ratio and $\mathrm{pH}(\mathrm{r}=-0.6-0.71, p<0.05)$. Three variables (SOC, silt and $\mathrm{pH}$ ) could estimate parameter $f\left(\mathrm{R}^{2}=0.72, p<0.01\right.$ ) well and two $(T \mathrm{~N}$ and $\mathrm{pH})$ for parameter $k\left(\mathrm{R}^{2}=0.61, p<0.01\right)$. The developed PTFs, integrating various land uses and soil depths, suggest that basic soil properties are helpful for estimation of anaerobic soil $\mathrm{N}$ mineralization.
\end{abstract}

\section{Keywords}

Nitrogen Mineralization, Pedotransfer Function, Soil Nutrient, Land Use

\section{Introduction}

Nitrogen is required for the survival of all living organisms on the earth. The 
balance of $\mathrm{N}$ cycle is critical to ensure the normal operation of global ecosystem [1]. Numbers of environmental problems, such as eutrophication, soil acidification and global warming, resulting from excessive $\mathrm{N}$ fertilizer application that disrupts soil $\mathrm{N}$ balance have been increasingly concerned [2] [3] [4]. Therefore, how to improve fertilizer $\mathrm{N}$ use efficiency has become an important issue in agronomic research [5], and quantifying the potential soil $\mathrm{N}$ mineralized is critical, which makes fertilization more reasonable.

Soil $\mathrm{N}$ mineralization is a complicated process, which converts organic $\mathrm{N}$ to inorganic forms (e.g., $\mathrm{NH}_{4}-\mathrm{N}$ and $\mathrm{NO}_{3}-\mathrm{N}$ ) via a variety of bacteria and fungi. Through incubation experiments, we can easily obtain soil $\mathrm{N}$ mineralization kinetics. Then empirical or semi-empirical models are used to fit the kinetic curve. The common models include the single model, double exponential model, and special model [6]. Many studies have shown that the two-pool, first-order exponential model, which contains active and resistant $\mathrm{N}$ pools with different mineralization rates, has generally been found to perform better [7]. Soil N mineralization occurs both in aerobic and anaerobic conditions. Generally, the study condition of soil $\mathrm{N}$ mineralization varies for different land uses, e.g., aerobic incubation condition for dry land, and anaerobic conditions for paddy soils. Due to the various water conditions, soil $\mathrm{N}$ mineralization potential differs. Smith et al. (1981) derived that forest soils had more potential $\mathrm{N}$ mineralized under an aerobic than anaerobic condition, whereas for agricultural soils, it showed the opposite [8]. Except for the land uses or oxygen condition, many other factors can also influence soil $\mathrm{N}$ mineralization, e.g., temperature, soil properties and even attitude [9] [10]. In aerobic condition, Dalias et al. (2002) demonstrated that soil $\mathrm{N}$ mineralization increases with the increase of temperature in the range of zero to $35^{\circ} \mathrm{C}$ [11], which might be suitable for anaerobic incubation condition [12]. As to soil properties, Haer and Benbi (2003) derived that soil organic C and clay content strongly affected the potential mineralized N [7]. Meanwhile, Narteh and Sahrawat (1997) indicated rice soil mineralized $\mathrm{N}$ was significantly related to organic $\mathrm{C}, \mathrm{pH}$, total $\mathrm{N}$, clay and $\mathrm{CEC}$, which suggested that using basic soil properties can possibly predict $\mathrm{N}$ mineralization [13].

Although many studies were reported on soil $\mathrm{N}$ mineralization, the development of equations to estimate anaerobic soil $\mathrm{N}$ mineralization for different land uses and various soil depths was seldom, especially in the area of central subtropical China, where high rate of chemical nitrogen was applied in agriculture. Besides, because of the spatial and temporal variability of soils, the data of soil $\mathrm{N}$ mineralization kinetics derived from time-consuming laboratory incubation cannot meet the demand of regional model simulations [14], however, which is solved by pedo-transfer functions (PTFs) approach. The PTFs are generally developed by correlating readily available data or easily measured soil properties with dynamic soil processes that are costly to measure [15]. Therefore, we selected a typical red-soil region in subtropical central China, and sampled from three major land uses and different soil depths. The two-pool exponent model 
was used to fit anaerobic soil $\mathrm{N}$ mineralization, and then we identified the important soil attributes that affect the parameters of anaerobic soil $\mathrm{N}$ mineralization dynamics. Finally, the local PTFs for these parameters were developed based on those significant soil properties.

\section{Materials and Methods}

The study site is located in a typical hilly town named Jinjing $\left(113^{\circ} 18-26^{\prime} \mathrm{E}\right.$, $28^{\circ} 30$ - 39'N; elevation of 50 - $430 \mathrm{~m}$; area: $135 \mathrm{~km}^{2}$ ) in Hunan Province, China, which is also developed as the agricultural and environmental monitoring station (Changsha station) in 2011 by Institute of Subtropical Agriculture, Chinese Academy of Sciences (CAS). This study area has a subtropical monsoon climate, with an annual average temperature of $17.2^{\circ} \mathrm{C}$ and an annual mean precipitation of 1200 - $1500 \mathrm{~mm}$ (during 1968-2012). The main soil types are Anthrosols and Ultisols, developed from Quaternary red earth and highly weathered granite parent materials [16]. Paddy fields (mainly for double-cropping rice, distributed in the river alluvium plains), woodlands (dominated by Masson pine and Chinese fir, distributed in the northern relatively steep hilly land) and tea fields (mainly distributed in the gentle slope land in central and southern area) are the dominated land uses, approximately accounting for $27 \%, 65 \%$ and $3 \%$ of total area, respectively. According to the survey from local farmers, urea and compound fertilizer are the main resources of chemical nitrogen. The rate of nitrogen for paddy fields is up to $375 \mathrm{~kg} \mathrm{~N} \mathrm{ha} \mathrm{kg}^{-1} \cdot \mathrm{yr}^{-1}$.

Twenty-four intact soil profiles $(50-\mathrm{cm}$ in depth and $9-\mathrm{cm}$ in diameter) from above dominated land uses were sampled respectively in 2010, using an auger machine (Stiboka, Standard set, 05.07, Eijkelkamp, Netherlands) that is suitable for undisturbed soil column collection without digging big pits. The sampling sites were randomly set but also considered the distribution of land uses and soil types, and in each site only one soil profile was sampled. All the $50-\mathrm{cm}$ depth soil profiles were stratified indoors with layers of $0-20 \mathrm{~cm}$ and $20-50 \mathrm{~cm}$ soil depths. Thus, 48 soil samples were obtained. The soil of each layer was air-dried, and then sieved to measure soil physical and chemical properties Table 1 . The SOC and $T \mathrm{~N}$ were determined via a dry combustion method using an automated C/N analyzer (Vario MAX, Elementar, Germany). Particle size distribution (Sand: 2.0 - $0.05 \mathrm{~mm}$; Silt: 0.05 - $0.002 \mathrm{~mm}$; Clay: less than 0.002 $\mathrm{mm}$ ) was measured by the hydrometer method. Soil $\mathrm{pH}$ was derived from a pH meter (Delta 320, Mettler-Toledo, Switzerland) with a soil-water ratio of $1: 2.5(\mathrm{w} / \mathrm{v})$.

Soil $\mathrm{N}$ mineralization was determined based on an anaerobic incubation experiment in the laboratory [6]. Air-dried soil samples in duplicate (sieved by a 2 $\mathrm{mm}$ mesh; $10 \mathrm{~g}$ weight for each) and $25 \mathrm{~mL}$ of deionized water were placed in each plastic bottle $(120 \mathrm{~mL})$, sealed, and then anaerobically incubated in the dark at $35^{\circ} \mathrm{C}$ for intervals of $0,7,14,21,28$ and 35 days. The samples from each interval of incubation time were extracted using $25 \mathrm{~mL}$ of a $4 \mathrm{~mol} \cdot \mathrm{L}^{-1}$ potassium 
Table 1. The basic soil properties of three typical land uses in various layers.

\begin{tabular}{|c|c|c|c|c|c|c|c|c|c|c|}
\hline \multirow{2}{*}{ Land use } & \multirow{2}{*}{ Site } & Layer & $\mathrm{TN}$ & SOC & Sand & Silt & Clay & $\mathrm{pH}$ & $\mathrm{NH}_{4}-\mathrm{N}$ & $\mathrm{NO}_{3}-\mathrm{N}$ \\
\hline & & $\mathrm{cm}$ & $\%$ & $\%$ & $\%$ & $\%$ & $\%$ & - & $\mathrm{mg} \cdot \mathrm{kg}^{-1}$ & $\mathrm{mg} \cdot \mathrm{kg}^{-1}$ \\
\hline \multirow[t]{8}{*}{ Woodland } & 1 & $20-50$ & 0.07 & 0.67 & 20.7 & 54.5 & 24.8 & 4.6 & 11.2 & 1.30 \\
\hline & 2 & $0-20$ & 0.07 & 0.67 & 76.7 & 9.70 & 13.6 & 4.5 & 8.30 & 31.3 \\
\hline & 2 & $20-50$ & 0.06 & 0.47 & 55.3 & 18.5 & 26.2 & 4.7 & 5.00 & 37.1 \\
\hline & 3 & $20-50$ & 0.06 & 0.51 & 27.1 & 47.2 & 25.7 & 5.1 & 7.70 & 61.0 \\
\hline & 4 & $20-50$ & 0.06 & 0.57 & 37.2 & 28.1 & 34.7 & 4.5 & 5.70 & 53.9 \\
\hline & 5 & $0-20$ & 0.07 & 0.60 & 59.5 & 20.7 & 19.9 & 4.2 & 8.70 & 7.60 \\
\hline & 6 & $0-20$ & 0.11 & 0.95 & 28.4 & 20.7 & 51.0 & 4.4 & 13.7 & 7.50 \\
\hline & 7 & $0-20$ & 0.06 & 0.62 & 69.5 & 13.7 & 16.7 & 4.6 & 11.9 & 9.40 \\
\hline \multirow[t]{4}{*}{ Tea garden } & 8 & $20-50$ & 0.11 & 0.83 & 50.2 & 20.9 & 28.9 & 3.4 & 14.7 & 1.50 \\
\hline & 9 & $20-50$ & 0.05 & 0.40 & 56.9 & 21.8 & 21.3 & 4.7 & 11.2 & 1.70 \\
\hline & 10 & $20-50$ & 0.08 & 0.78 & 49.1 & 22.1 & 28.8 & 4.8 & 16.5 & 1.60 \\
\hline & 11 & $0-20$ & 0.07 & 0.68 & 42.4 & 24.4 & 33.2 & 4.4 & 17.3 & 6.40 \\
\hline \multirow[t]{15}{*}{ Paddy field } & 12 & $0-20$ & 0.29 & 2.03 & 14.4 & 54.7 & 31.0 & 4.2 & 53.2 & 58.9 \\
\hline & 12 & $20-50$ & 0.15 & 0.85 & 16.2 & 58.7 & 25.1 & 5.4 & 16.3 & 20.8 \\
\hline & 13 & $0-20$ & 0.25 & 1.71 & 30.0 & 42.1 & 28.0 & 4.6 & 41.9 & 65.1 \\
\hline & 13 & $20-50$ & 0.14 & 0.83 & 29.0 & 42.4 & 28.6 & 5.7 & 12.5 & 7.00 \\
\hline & 14 & $0-20$ & 0.18 & 1.03 & 19.6 & 51.2 & 29.2 & 4.7 & 32.7 & 26.0 \\
\hline & 15 & $0-20$ & 0.23 & 1.68 & 53.8 & 29.9 & 16.3 & 5.0 & 32.8 & 7.90 \\
\hline & 16 & $0-20$ & 0.21 & 1.35 & 41.9 & 33.7 & 24.4 & 4.8 & 34.7 & 45.5 \\
\hline & 17 & $0-20$ & 0.18 & 1.08 & 42.4 & 33.9 & 23.7 & 5.0 & 30.1 & 18.4 \\
\hline & 18 & $0-20$ & 0.18 & 1.15 & 47.2 & 33.6 & 19.2 & 5.8 & 31.3 & 11.7 \\
\hline & 19 & $0-20$ & 0.26 & 1.79 & 39.2 & 37.9 & 22.9 & 4.9 & 35.7 & 60.4 \\
\hline & 20 & $0-20$ & 0.19 & 1.02 & 39.5 & 38.7 & 21.8 & 5.7 & 34.9 & 51.5 \\
\hline & 21 & $0-20$ & 0.28 & 1.64 & 16.1 & 68.4 & 15.5 & 6.8 & 34.8 & 84.6 \\
\hline & 22 & $0-20$ & 0.25 & 1.63 & 36.3 & 41.5 & 22.2 & 5.5 & 46.0 & 41.8 \\
\hline & 23 & $0-20$ & 0.27 & 1.69 & 22.9 & 52.8 & 24.3 & 4.9 & 45.1 & 54.7 \\
\hline & 24 & $0-20$ & 0.21 & 1.39 & 50.2 & 31.9 & 17.9 & 6.2 & 38.4 & 39.5 \\
\hline
\end{tabular}

a) $\mathrm{TN}$ is total soil N; SOC is soil organic C; Sand, Silt and Clay are soil sand, silt and clay particle content, respectively. $\mathrm{pH}$ denotes soil $\mathrm{pH}$ value. $\mathrm{NH}_{4}-\mathrm{N}$ and $\mathrm{NO}_{3}-\mathrm{N}$ refer to soil ammonium $\mathrm{N}$ and nitrate $\mathrm{N}$ concentration, respectively.

chloride solution, shaken for $1 \mathrm{~h}$, and then filtered. Nitrate nitrogen $\left(\mathrm{NO}_{3}-\mathrm{N}\right)$ and ammonium nitrogen $\left(\mathrm{NH}_{4}-\mathrm{N}\right)$ were measured in the filtrates using a flow injection analyzer (FIAstar5000, Foss, Sweden). Restricted to the amount of soil for many layers, soil $\mathrm{N}$ mineralization kinetics could not be measured again once failed, therefore, 27 soil samples comprised of different soil depth layers were lastly selected for analysis. 
A modified double first-order kinetic model was used to fit the anaerobic soil $\mathrm{N}$ mineralization, then Pearson's correlation analysis was conducted to analyze the relationship between the fitted parameters of anaerobic soil $\mathrm{N}$ mineralization kinetics and basic soil properties, and eventually we developed the PTFs to predict the parameters using multiple stepwise linear regression method. Coefficient of determination $\left(\mathrm{R}^{2}\right)$, as well as RMSE derived from ten-fold cross validation technique, was used to assess the predictive capability of PTFs. The modified double first-order kinetic model was expressed as:

$$
N_{\min }=T N \cdot 10^{4} \cdot\left\{f \cdot[1-\exp (-k \cdot t)]+(1-f) \cdot\left[1-\exp \left(-k_{r} \cdot t\right)\right]\right\}
$$

where $N_{\text {min }}$ denotes net soil $\mathrm{N}$ mineralized $\left(\mathrm{mg} \cdot \mathrm{kg}^{-1}\right)$ within incubation time of $t$ (d); $T \mathrm{~N}$ is total soil $\mathrm{N}(\%) ;$ frepresents the fraction of soil active $\mathrm{N}$ pool $(0-1) ; k$ and $k_{r}$ are mineralization rate constants for soil active $\mathrm{N}$ pool and resistant $\mathrm{N}$ $\left(\mathrm{d}^{-1}\right)$ pool, respectively. During the fitting process of soil $\mathrm{N}$ mineralization, we found a definite value of $1.5 \times 10^{-6} \mathrm{~d}^{-1}$ assigned to the parameter of $k_{r}$ performed better.

The fitting procedure for soil $\mathrm{N}$ mineralization was implemented in Microsoft Excel 2013 using Solver function with a least square method. The PTFs for the parameters ( $f$ and $k$ ) based on soil properties were developed using $\mathrm{R}$ software, as well as graphs plotting and mathematic statistics. Ten-fold cross validation was carried out in R using DAAG package.

\section{Results and Discussion}

\subsection{Anaerobic Soil N Mineralization and Significant Factors}

In an anaerobic incubation environment (waterlogged and flooded), soil nitrification which requires oxygen is inhibited, and ammonification becomes the major process during soil $\mathrm{N}$ mineralization; thus, ammonium $\mathrm{N}$ accumulates as the final product. Meanwhile, original nitrate $\mathrm{N}$ in the soil is quickly converted to gaseous $\mathrm{N}$ by de-nitrification or being assimilated by microbes. In our incubation experiment, due to the insufficiency of oxygen, the concentration of soil nitrate $\mathrm{N}$ for all soil samples quickly decreased to close to zero within 7 days of incubation (not shown in tables or figures). Soil ammonium $\mathrm{N}$ was released rapidly within initial two weeks, and subsequently became slow, being stable within the 35-d incubation Figure 1, which meant the incubation system got the balance between $\mathrm{N}$ mineralization and immobilization. The flush increase of ammonium $\mathrm{N}$ could be the result of rewetting of dry soil [17], which should not be ignored in anaerobic soil $\mathrm{N}$ mineralization especially for dry land soil, because soil rewetting is a natural phenomenon. A similar result was also obtained by Li et al. (2003) for the study of anaerobic soil $\mathrm{N}$ mineralization in paddy fields of the Taihu region of China [6]. From the literatures, the incubation time for soil $\mathrm{N}$ mineralization is still debatable. Long duration provides detailed information of soil $\mathrm{N}$ mineralization, but leads to be costly and more harmful to microbe activities because of continuous accumulation of ammonium ion [18]. However, 

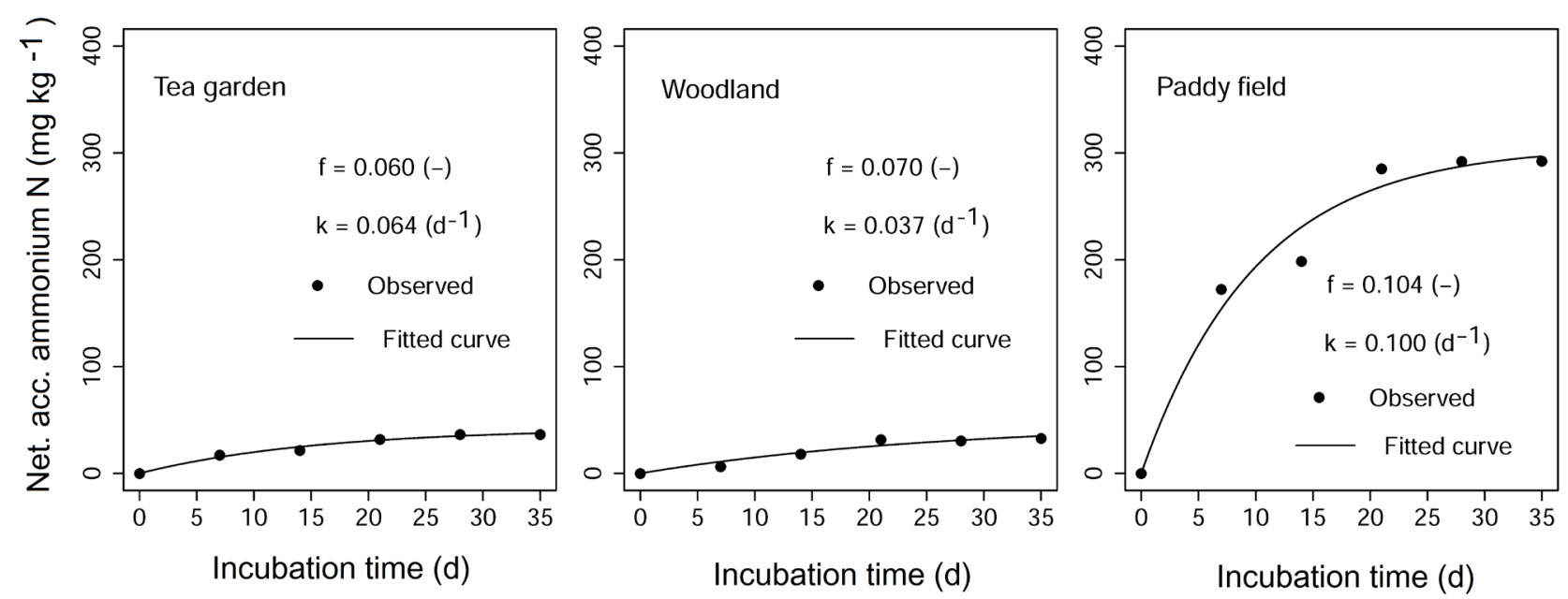

Figure 1. The change of soil net accumulated ammonium $\mathrm{N}$ concentration (net acc. ammonium, $\mathrm{mg} \mathrm{N} \mathrm{kg}^{-1}$ ) over incubation time $(t)$ under anaerobic conditions and the fitted curves using a modified double first-order kinetic model for various land uses. $f$ is the fraction of soil active $\mathrm{N}$ pool $(0-1) ; k$ denotes soil active $\mathrm{N}$ mineralization rate constant $\left(\mathrm{d}^{-1}\right)$.

a reasonable high temperature can accelerate the procedure of soil $\mathrm{N}$ mineralization. Bronson et al. (2001) found that $7-\mathrm{d}$ incubation at $40^{\circ} \mathrm{C}$ in an anaerobic condition is enough for an accurate estimation of soil $\mathrm{N}$ mineralization potential for paddy soils [19]. Relative to aerobic incubation, soil $\mathrm{N}$ mineralization in anaerobic condition showed simpler, in which only ammonification was considered. Meanwhile, the incubation conditions employed in our study are rational.

The modified double first-order kinetic model fitted anaerobic soil $\mathrm{N}$ mineralization well $\left(\mathrm{R}^{2}=0.90-0.99, p<0.01\right)$, which agreed with Inubushi et al. (1985) [20]. Both of the fitted parameters of $f$ and $k$ for all soil samples $(\mathrm{N}=27)$ approximately presented normal distributions, and ranged from $1.59 \%$ to $10.4 \%$ with an average value of $5.2 \%$ for $f$, and from 0.027 to $0.155 \mathrm{~d}^{-1}$ with a mean value of $0.97 \mathrm{~d}^{-1}$ for $k$, respectively Figure 2 . The average amount of potentially soil anaerobic mineralizable $\mathrm{N}$ in paddy fields was greater than that in woodlands or tea fields Figure 1, which perhaps because paddy fields are generally waterlogged for long periods than woodlands and tea fields, resulting in more abundant microbes in paddy soils that can exist in anaerobic conditions. Smith et al. (1981) compared the soil potential N mineralized in aerobic and anaerobic condition for forest soils and agricultural soils, respectively, and indicated that forest soils had higher potential $\mathrm{N}$ mineralized under an aerobic condition, relative to in an anaerobic environment [8]. However, agricultural soils presented more mineralized $\mathrm{N}$ in an anaerobic condition than in an aerobic incubation. As shown in Table 1, both of the two parameters had a medium coefficient of variation $(\mathrm{CV})(10<\mathrm{CV}<100)$, as did other basic soil properties, e.g., $T \mathrm{~N}$, SOC, Sand, Silt, Clay, and $\mathrm{pH}$. The initial ammonium $\mathrm{N}$ and nitrate $\mathrm{N}$ in paddy soils were relatively greater than that in woodlands and tea fields.

Pearson's correlation analysis demonstrated that the fraction of soil active $\mathrm{N}$ pool $(f)$ was mainly positively correlated with soil $T \mathrm{~N}(r=0.66, p<0.01)$, SOC $(r$ $=0.69, p<0.01)$, and Silt $(r=0.66, p<0.01)$ and negatively related to Sand content 

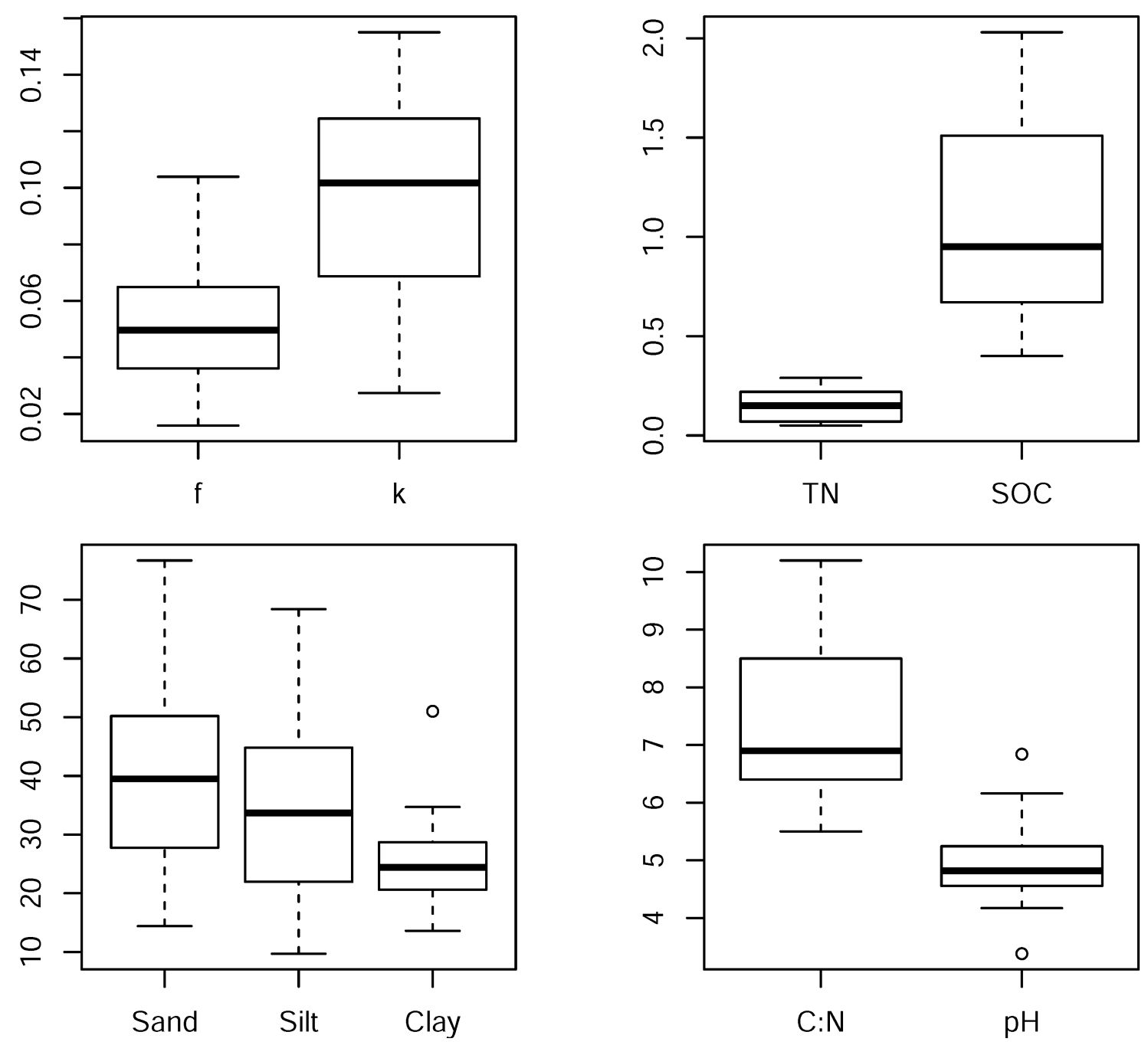

Figure 2. The distributions of soil basic properties and parameters of soil $\mathrm{N}$ mineralization dynamics fitted by the modified double first-order kinetic model. $f$ is the fraction of active $\mathrm{N}$ pool $(0-1) ; k$ is soil active $\mathrm{N}$ mineralization rate constant $\left(\mathrm{d}^{-1}\right)$; $T \mathrm{~N}$ is soil total $\mathrm{N}(\%)$; SOC is soil organic C (\%); C: $\mathrm{N}$ refers to soil organic C-to-total $\mathrm{N}$ ratio (fraction); Sand, Silt and Clay are soil sand, silt and clay particle contents, respectively (\%); $\mathrm{pH}$ refers to soil $\mathrm{pH}$ value.

$(r=-0.59, p<0.01)$ (Figure 3). As the mineralization of organic $\mathrm{N}$ was expected to be carried out by heterotrophic microorganisms which require organic matter as a substrate and energy to grow. Hence, the amounts of $T \mathrm{~N}$ and SOC could determine the rate and extent of $\mathrm{N}$ mineralization. Bronson et al. (2001) also found that potentially mineralizable $\mathrm{N}$ estimated after $84 \mathrm{~d}$ of anaerobic incubation at $30^{\circ} \mathrm{C}$ for rice soils was highly correlated with SOC and organic N [19]. Meanwhile, Narteh and Sahrawat (1997) indicated mineralized N was significantly related to $\mathrm{pH}, \mathrm{SOC}, \mathrm{TN}$ and Clay content, but not with $\mathrm{C}$ : $\mathrm{N}$ ratio in their study of wetland rice soils in West Africa [13]. However, from the correlation analysis in our study (Figure 3 ), soil $\mathrm{N}$ mineralization rate constant $(k)$ was significantly related to $T \mathrm{~N}(r=0.71, p<0.01)$, SOC $(r=0.64, p<0.01), \mathrm{C}$ : $\mathrm{N}$ ratio $(r=-0.60, p<0.01)$, and $\mathrm{pH}(r=0.56, p<0.01)$, as well as Clay content $(r=$ 
$-0.40, p<0.05$ ), which was in accord with the study of Haddad et al. (2013) [21]. The soil with high $\mathrm{C}$ : $\mathrm{N}$ ratio was not easily decomposed due to lack of $\mathrm{N}$ supply. Meanwhile, as clay particle content increased, more organic $\mathrm{N}$ would be wrapped and difficulty being attacked by microorganisms. As shown in Figure 3 , significant relationships existed between some soil properties, such as $T \mathrm{~N}$ and SOC $(r=0.97, p<0.01)$, which should be paid attention to avoid co-linearity between variables when developing the PTFs for the rate constant or potentially mineralized $\mathrm{N}$.

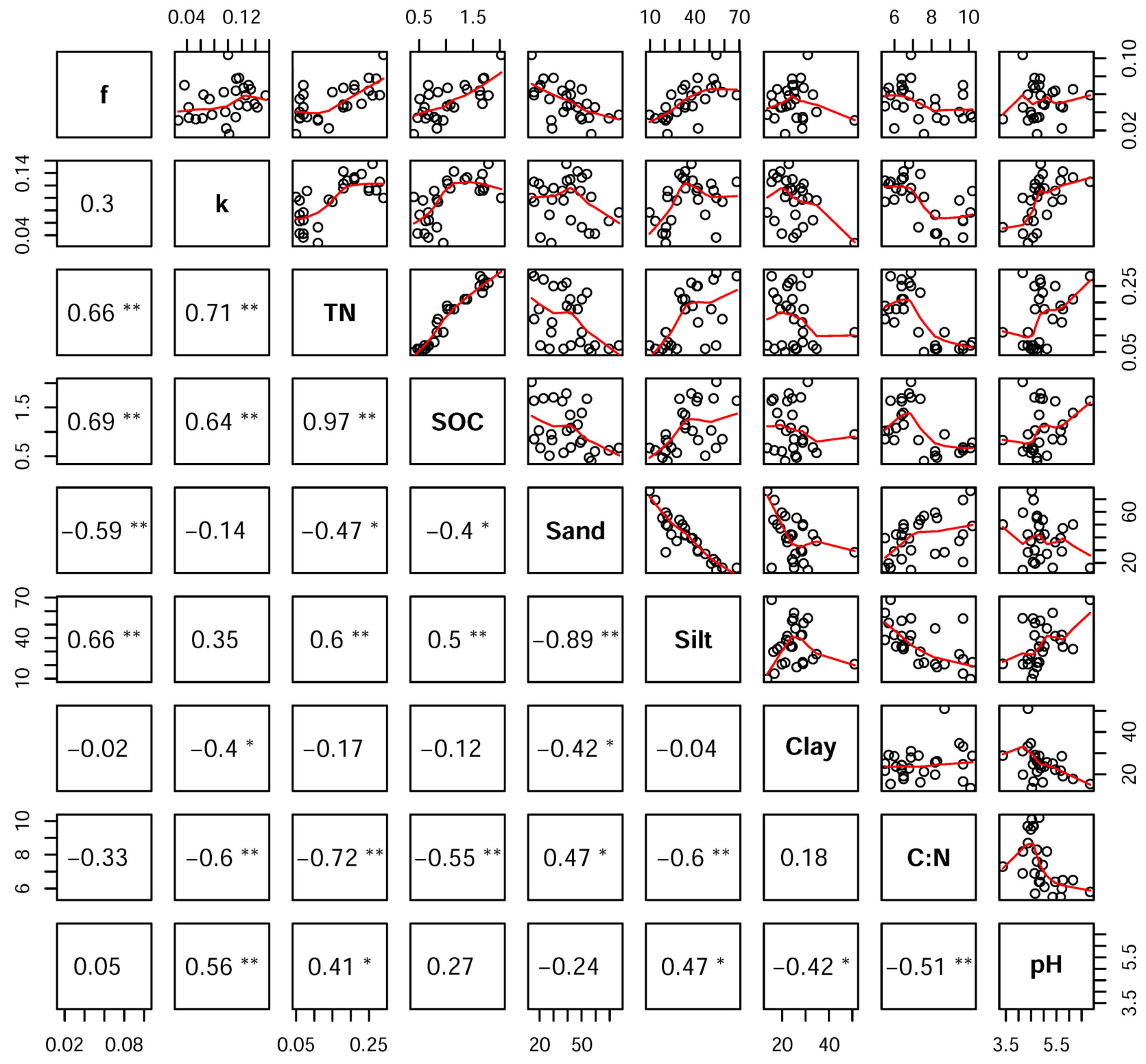

Figure 3. The correlation matrix between soil $\mathrm{N}$ mineralization parameters and basic soil properties. The lower triangle shows correlation coefficients, and the upper-triangle displays scatter plots. $f$ is the fraction of soil active $\mathrm{N}$ pool $(0-1) ; k$ is soil active $\mathrm{N}$ mineralization rate constant $\left(\mathrm{d}^{-1}\right)$; $\mathrm{TN}$ is soil total $\mathrm{N}(\%)$; SOC is soil organic $\mathrm{C}(\%)$; C: $\mathrm{N}$ refers to soil organic C-to-total $\mathrm{N}$ ratio (fraction); Sand, Silt and Clay are soil sand, silt and clay particle contents, respectively (\%); $\mathrm{pH}$ refers to soil $\mathrm{pH}$ value. ${ }^{\star}: p<0.05$; ${ }^{*}: p<0.01$. 


\subsection{Development of PTFs}

The predictive PTFs for the fitted two parameters of anaerobic soil $\mathrm{N}$ mineralization dynamics were derived through multiple stepwise linear regression method from significant basic soil properties Table 2. Three variables (SOC, Silt and $\mathrm{pH})$ were finally selected to estimate the parameter $f\left(\mathrm{R}^{2}=0.72\right.$, RMSE $=$ $0.013, p<0.01)$. Sahrawat (1983) had demonstrated that SOC was a good index to predict soil mineralizable $\mathrm{N}$ in tropical wetland rice soils [22], and Narteh and Sahrawat (1997) proposed a simple equation to estimate anaerobic soil mineralized $\mathrm{N}$ for wetland rice soils in West Africa based on extractable iron, Clay and $\mathrm{pH}\left(\mathrm{R}^{2}=0.78\right)[13]$. From the correlation analysis Figure 3, SOC and Silt were significantly correlated with parameter $f(p<0.01)$, but there was a poor relationship between parameter $f$ and $\mathrm{pH}(\mathrm{r}=0.05)$, however, absence of $\mathrm{pH}$ in the PTF for estimation of parameter $f$ would reduce its accuracy $\left(\mathrm{R}^{2}=0.61\right)$. Whereas the $\mathrm{pH}$ had great correlation with parameter $k(\mathrm{r}=0.56, p<0.01)$, and a PTF using $7 \mathrm{~N}$ and $\mathrm{pH}$ (with a reciprocal transformation) as the predictors predicted the parameter $k$ well, explaining $61 \%$ of its variability. Although SOC was significantly related to $\mathrm{TN}(p<0.01)$, using SOC and $\mathrm{pH}$ as the variables to estimate parameter $k$ performed relative poorer but also acceptable $\left(\mathrm{R}^{2}=0.59\right)$. As shown in the 1:1 plots Figure 4, the PTF for $f$ derived in our study outperformed $k$ 's model, implying that $\mathrm{N}$ mineralization rate constant $(k)$ might be affected by other important factors which were not considered in the present study, such as extractable iron. However, the essence of PTF is to predict those difficulty properties using some easily available or measured attributes [15]. The soil properties of SOC, $T \mathrm{~N}, \mathrm{pH}$ and particle size content are easily determined or available from soil survey database.

The derived PTFs are convenient to get soil $\mathrm{N}$ mineralization in an anaerobic condition. However, we propose a cautious implementation of the PTFs and suggest that similar incubation methods and soil types or land uses are necessary. Meanwhile, the pretreatment techniques of soil samples are also important [23]. In this study, disturbed soils were used to determine soil $\mathrm{N}$ mineralization dynamics, while many studies had reported that potentially mineralized $\mathrm{N}$ in disturbed soils was higher than that in undisturbed soils or field soils [24], because more protected organic matter was used in soils after being disturbed.

Table 2. The PTFs for parameters of anaerobic soil $\mathrm{N}$ mineralization dynamics and their predictive accuracy.

\begin{tabular}{ccc}
\hline PTFs & $\mathrm{R}^{2}$ & RMSE \\
\hline$f=0.029+0.021 \cdot$ SOC $+0.00076 \cdot$ Silt $-0.001 \cdot \mathrm{pH}^{2}$ & 0.72 & 0.01 \\
$k=0.15+0.25 \cdot T N-\frac{0.44}{\mathrm{pH}}$ & 0.61 & 0.02 \\
\hline
\end{tabular}

a) $\mathrm{R}^{2}$ is coefficient of determination of model; RMSE is root mean square error derived by ten-fold cross validation. b) $f$ is the ratio of active $\mathrm{N}$ pool to total soil $\mathrm{N}$ (fraction); $k$ denotes $\mathrm{N}$ mineralization rate constant $\left(\mathrm{d}^{-1}\right)$; SOC is soil organic C (\%); $\mathrm{TN}$ is soil total $\mathrm{N}(\%)$; Silt is soil silt particle content (\%); and pH refers to soil $\mathrm{pH}$ value. 

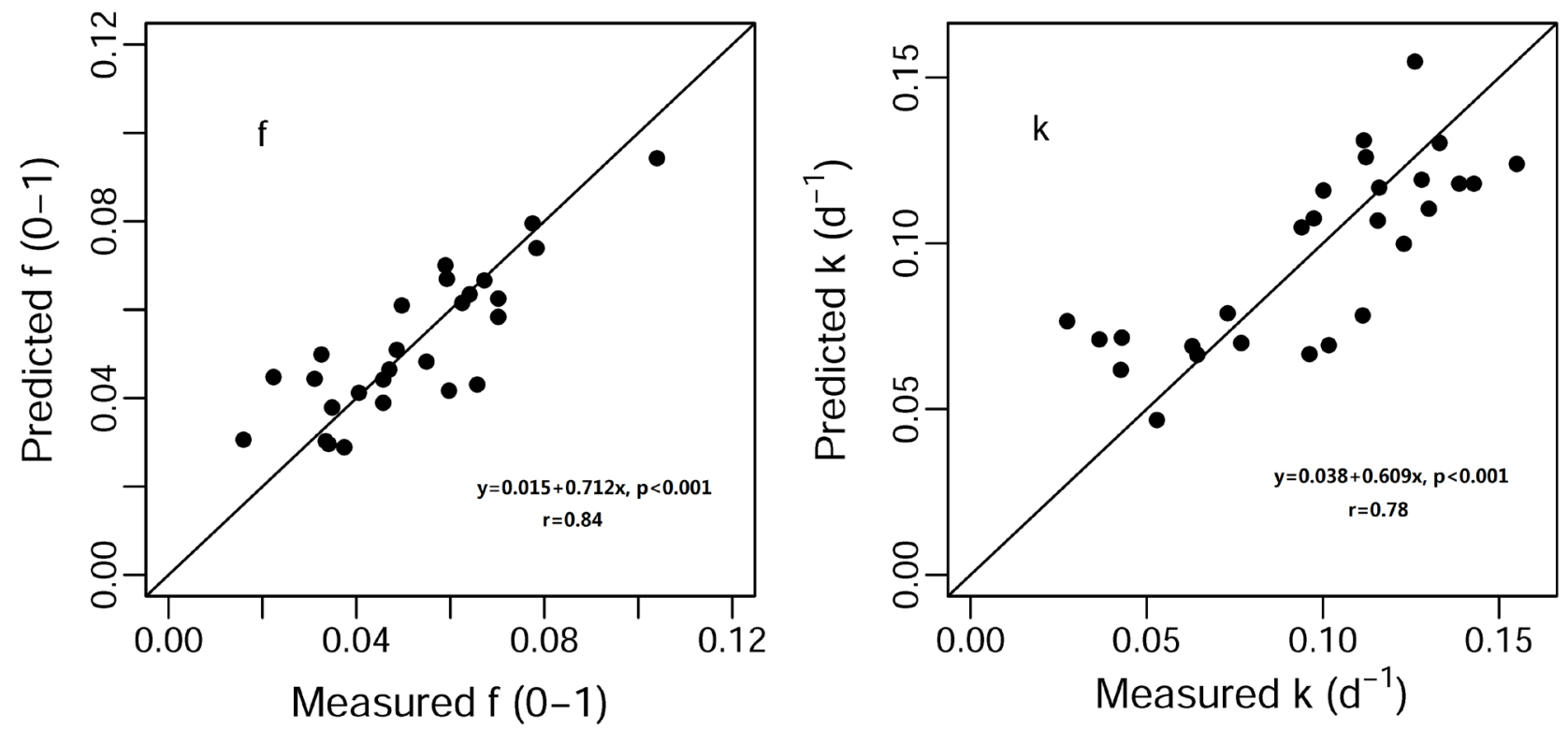

Figure 4. The 1:1 plot between measured and predicted values of soil $\mathrm{N}$ mineralization parameters. $f$ is the fraction of soil active $\mathrm{N}$ pool $(0-1) ; k$ is soil active $\mathrm{N}$ mineralization rate constant $\left(\mathrm{d}^{-1}\right) ; r$ denotes the correlation coefficient between measured and predicted values.

Moreover, we ignored the initial flush ("birch effects") within initial two weeks because rewetting was a natural phenomenon for soils, such as after a rainstorm or irrigation. Eventually, the modified double exponential model was used and simplified the prediction of soil $\mathrm{N}$ mineralization. The most important point was that the derived PTFs could be also suitable for parametric estimations of anaerobic soil $\mathrm{N}$ mineralization dynamics for the subsoils and dry land soils, which were not usually considered by many other studies.

\section{Conclusion}

An investigation was carried out for the parametric estimation of anaerobic soil $\mathrm{N}$ mineralization dynamics in a typical red-soil region in subtropical central China. A modified double exponential model fitted soil $\mathrm{N}$ mineralization well, with a range of $1.59 \%-10.4 \%$ and a mean value of $5.2 \%$ out of total soil $\mathrm{N}$ for the parameter $f$, and a range of $0.027-0.155 \mathrm{~d}^{-1}$ with a mean value of $0.97 \mathrm{~d}^{-1}$ for parameter $k$ at incubation conditions of $35^{\circ} \mathrm{C}$. The parameter $f$ was significantly correlated with $T \mathrm{~N}, \mathrm{SOC}$, Sand, and Silt content $(p<0.01)$, while parameter $k$ was mainly influenced by $T \mathrm{~N}$, SOC, Clay content, $\mathrm{C}: \mathrm{N}$ ratio and $\mathrm{pH}$. Using SOC, Silt and $\mathrm{pH}$ as the predictors could well predict the parameter $f\left(\mathrm{R}^{2}=0.72\right)$ and two variables $(T \mathrm{~N}$ and $\mathrm{pH})$ for estimation of parameter $k\left(\mathrm{R}^{2}=0.61\right)$. The derived PTFs are useful and convenient for anaerobic soil $\mathrm{N}$ mineralization prediction, especially for the red soil in subtropical China, besides, they can also apply to various land uses, as well as different soil depths. By combing with aerobic soil $\mathrm{N}$ mineralization, we can quickly quantify the soil $\mathrm{N}$ potential supply in such place or similar areas or soils. 


\section{Acknowledgements}

Appreciation is granted to the financial support by the National Natural Science Foundation of China (31401945) and the National key Basic Research Program of China (2012CB417105).

\section{References}

[1] Canfield, D.E., Glazer, A.N. and Falkowski, P.G. (2010) The Evolution and Future of Earth's Nitrogen Cycle. Science, 330, 192-196.

https://doi.org/10.1126/science.1186120

[2] Barak, P., Jobe, B.O., Krueger, A.R., Peterson, L.A. and Laird, D.A. (1997) Effects of Long-Term Soil Acidification Due to Nitrogen Fertilizer Inputs in Wisconsin. Plant and Soil, 197, 61-69. https://doi.org/10.1023/A:1004297607070

[3] Smith, K.A., McTaggart, I.P. and Tsuruta, H. (1997) Emissions of $\mathrm{N}_{2} \mathrm{O}$ and NO Associated with Nitrogen Fertilization in Intensive Agriculture, and the Potential for Mitigation. Soil Use and Management, 13, 296-304. https://doi.org/10.1111/j.1475-2743.1997.tb00601.x

[4] McIsaac, G.F., David, M.B., Gertner, G.Z. and Goolsby, D.A. (2001) Eutrophication: Nitrate Flux in the Mississippi River. Nature, 414, 166-167.

https://doi.org/10.1038/35102672

[5] Ladha, J.K., Pathak, H., Krupnik, T., Six, J. and van Kessel, C. (2005) Efficiency of Fertilizer Nitrogen in Cereal Production: Retrospects and Prospects. Advances in Agronomy, 87, 85-156. https://doi.org/10.1016/S0065-2113(05)87003-8

[6] Li, H., Han, Y. and Cai, Z. (2003) Nitrogen Mineralization in Paddy Soils of the Taihu Region of China under Anaerobic Conditions: Dynamics and Model Fitting. Geoderma, 115, 161-175. https://doi.org/10.1016/S0016-7061(02)00358-0

[7] Haer, H.S. and Benbi, D.K. (2003) Modeling Nitrogen Mineralization Kinetics in Arable Soils of Semiarid India. Arid Land Research Management, 17, 153-168. https://doi.org/10.1080/15324980301586

[8] Smith, J.L., McNeal, B.L., Owens, E.J. and Klock, G.O. (1981) Comparison of Nitrogen Mineralized under Anaerobic and Aerobic Conditions for Some Agricultural and Forest Soils of Washington. Communications in Soil Science and Plant Analysis, 12, 997-1009. https://doi.org/10.1080/00103628109367212

[9] Guntiñas, M.E., Leirós, M.C., Trasar-Cepeda, C. and Gil-Sotres, F. (2012) Effects of Moisture and Temperature on Net Soil Nitrogen Mineralization: A Laboratory Study. European Journal of Soil Biology, 48, 73-80. https://doi.org/10.1016/j.ejsobi.2011.07.015

[10] Zhang, S., Chen, D., Sun, D., Wang, X., Smith, J.L. and Du, G. (2012) Impacts of Altitude and Position on the Rates of Soil Nitrogen Mineralization and Nitrification in Alpine Meadows on the Eastern Qinghai-Tibetan Plateau, China. Biology and Fertility of Soils, 48, 393-400. https://doi.org/10.1007/s00374-011-0634-5

[11] Dalias, P., Anderson, J.M., Bottner, P. and Coûteaux, M. (2002) Temperature Responses of Net Nitrogen Mineralization and Nitrification in Conifer Forest Soils Incubated under Standard Laboratory Conditions. Soil Biology \& Biochemistry, 34, 691-701. https://doi.org/10.1016/S0038-0717(01)00234-6

[12] Angus, J.F., Ohnishi, M., Horie, T. and Williams, R.L. (1994) A Preliminary Study to Predict Net Nitrogen Mineralisation in a Flooded Rice Soil using Anaerobic Incubation. Animal Production Science, 34, 995-999.

https://doi.org/10.1071/EA9940995 
[13] Narteh, L.T. and Sahrawat, K.L. (1997) Potentially Mineralizable Nitrogen in West African Lowland Rice Soils. Geoderma, 76, 145-154. https://doi.org/10.1016/S0016-7061(96)00097-3

[14] Li, Y., White, R., Chen, D., Zhang, J., Li, B., Zhang, Y., Huang, Y. and Edis, R. (2007) A Spatially Referenced Water and Nitrogen Management Model (WNMM) for (Irrigated) Intensive Cropping Systems in the North China Plain. Ecological Modelling, 203, 395-423. https://doi.org/10.1016/j.ecolmodel.2006.12.011

[15] Minasny, B. and Hartemink, A.E. (2011) Predicting Soil Properties in the Tropics. Earth-Science Reviews, 106, 52-62. https://doi.org/10.1016/j.earscirev.2011.01.005

[16] Soil Survey Staff (2010) Keys to Soil Taxonomy. 11th Edition, USDA, Washington DC.

[17] Xiang, S.R., Doyle, A., Holden, P.A. and Schimel, J.P. (2008) Drying and Rewetting Effects on $\mathrm{C}$ and N Mineralization and Microbial Activity in Surface and Subsurface California Grassland Soils. Soil Biology \& Biochemistry, 40, 2281-2289. https://doi.org/10.1016/j.soilbio.2008.05.004

[18] Müller, T., Walter, B., Wirtz, A. and Burkovski, A. (2006) Ammonium Toxicity in Bacteria. Current Microbiology, 52, 400-406.

https://doi.org/10.1007/s00284-005-0370-x

[19] Bronson, K.F., Abao, J.E.B., Singh, B., Singh, Y., Singh, Y., Panuallah, G.M. and Regmi, A.P. (2001) Predicting Potential Anaerobic Nitrogen Mineralization of Rice-Rice and Rice-Wheat Soils of Asia. Communications in Soil Science and Plant Analysis, 32, 2411-2424. https://doi.org/10.1081/CSS-120000381

[20] Inubushi, K., Wada, H. and Takai, Y. (1985) Easily Decomposable Organic Matter in Paddy Soil: VI. Kinetics of Nitrogen Mineralization in Submerged Soils. Soil Science and Plant Nutrition, 31, 563-572. https://doi.org/10.1080/00380768.1985.10557464

[21] Haddad, S.A., Tabatabai, M.A. and Loynachan, T.E. (2013) Biochemical Processes Controlling Soil Nitrogen Mineralization under Waterlogged Conditions. Soil Science Society of America Journal, 77, 809-816. https://doi.org/10.2136/sssaj2012.0231

[22] Sahrawat, K.L. (1983) Mineralization of Soil Organic Nitrogen under Waterlogged Conditions in Relation to Other Properties of Tropical Rice Soils. Soil Research, 21, 133-138. https://doi.org/10.1071/SR9830133

[23] Benbi, D. and Richter, J. (2002) A Critical Review of Some Approaches to Modelling Nitrogen Mineralization. Biology and Fertility of Soils, 35, 168-183. https://doi.org/10.1007/s00374-002-0456-6

[24] Li, S.Q., Zhao, K. and Lu, H.L. (2013) Nitrogen Mineralization Characteristics of Disturbed and Undisturbed Soil Samples for Four Main Soil Types on the Loess Plateau. Communications in Soil Science and Plant Analysis, 44, 1659-1673. https://doi.org/10.1080/00103624.2013.783056 